\title{
Article
}

\section{Does the Low-Carbon City Pilot Policy Promote Green Technology Innovation? Based on Green Patent Data of Chinese A-Share Listed Companies}

\author{
Jintao Ma ${ }^{1}$, Qiuguang $\mathrm{Hu}^{1,2, *}$, Weiteng Shen ${ }^{1}$ and Xinyi Wei ${ }^{1}$ \\ 1 School of Business, Ningbo University, Ningbo 315211, China; moshanke@163.com (J.M.); \\ 1801092003@nbu.edu.cn (W.S.); 2001010006@nbu.edu.cn (X.W.) \\ 2 East China Sea Institute, Ningbo University, Ningbo 315211, China \\ * Correspondence: huqiuguang@nbu.edu.cn
}

Citation: Ma, J.; Hu, Q.; Shen, W.; Wei, X. Does the Low-Carbon City Pilot Policy Promote Green Technology Innovation? Based on Green Patent Data of Chinese A-Share Listed Companies. Int. J. Environ. Res. Public Health 2021, 18, 3695. https:// doi.org/10.3390/ijerph18073695

Academic Editor: Paul Tchounwou

Received: 14 March 2021

Accepted: 29 March 2021

Published: 1 April 2021

Publisher's Note: MDPI stays neutral with regard to jurisdictional claims in published maps and institutional affiliations.

Copyright: (c) 2021 by the authors. Licensee MDPI, Basel, Switzerland. This article is an open access article distributed under the terms and conditions of the Creative Commons Attribution (CC BY) license (https:/ / creativecommons.org/licenses/by/ $4.0 /)$.

\begin{abstract}
To cope with climate change and achieve sustainable development, low-carbon city pilot policies have been implemented. An objective assessment of the performance of these policies facilitates not only the implementation of relevant work in pilot areas, but also the further promotion of these policies. This study uses A-share listed enterprises from 2005 to 2019 and creates a multiperiod difference-in-differences model to explore the impact of low-carbon city pilot policies on corporate green technology innovation from multiple dimensions. Results show that (1) low-carbon city pilot policies stimulates the green technological innovation of enterprises as manifested in their application of green invention patents; (2) the introduction of pilot policies is highly conducive to green technological innovation in eastern cities and enterprises in high-carbon emission industries; and (3) tax incentives and government subsidies are important fiscal and taxation tools that play the role of pilot policies in low-carbon cities. By alleviating corporate financing constraints, these policies effectively promote the green technological innovation of enterprises. This study expands the research on the performance of low-carbon city pilot policies and provides data support for a followup implementation and promotion of policies from the micro perspective at the enterprise level.
\end{abstract}

Keywords: low-carbon city pilot policy; corporate green technological innovation; multi-period DID

\section{Introduction}

China's economic development has entered a new normal, but the excessive growth of its carbon emissions has restricted its long-term economic development. To fulfill energy conservation and emission reduction goals while realizing sustainable development, the pilot construction of low-carbon cities came into being. The Chinese government follows the logic of "from point to surface". Under the authorization of the central government, local governments independently carry out low-carbon city pilot work, and the central government absorbs the best of them into the policies formulated by the central government, and then promotes them nationwide. The first batch of low-carbon pilot projects were launched in 2010. After several years of development, 6 provinces and 81 cities were included in this project. Each pilot attaches great importance to low-carbon development planning and introduced relevant policies based on objective factors, such as resource endowments and industrial structure, with an emphasis on a coordinated economic development and environmental optimization. The construction of low-carbon cities requires an urgent improvement of the existing resource allocation mechanism and a transformation and upgrading of high-energy-consuming industries. As an important entity that gives full play to the role of the market in improving energy efficiency and optimizing energy structure, the innovation of enterprises in the field of green technology plays a key role in transforming economic models. In 2020, low-carbon pilot works were launched nationwide. As a result, the performance of environmental regulations, such as low-carbon city pilot policies, began to attract research attention. 
Many researchers at home and abroad have explored the impact of environmental regulation policies on green technology innovation. Most of these studies have analyzed the impact of environmental regulations on green technology innovation based on the "Porter hypothesis." Given the objective differences in their samples and measurement methods, these studies have proposed three main views. First, environmental regulations inhibit green technological innovation. Some scholars believe that the environmental regulations that increase the cost of pollution control has led to an overall decline in industrial performance [1], squeezed research and development (R\&D) investments, and inhibited corporate innovation in the field of green technology [2,3]. For instance, Chintrakarn [4] pointed out that environmental regulations have not promoted the US manufacturing sector. As efficiency is improved, Zhang [5] found that regulated companies mainly purchase new pollution control equipment to reach clean production standards instead of increasing the intensity of their R\&D and innovation. Second, environmental regulations promote green technological innovation. Many scholars [6-8] find that the "innovation compensation" effect stimulated by environmental regulation policies effectively promotes the innovation of enterprises in the field of green technology. Jing [9] argued that reasonable environmental regulation promotes the low-carbon transformation of industrial enterprises, Jia [10] and Wang [11] pointed out that strengthening environmental regulations can promote green technology innovation, and Qi [12] found that pilot emissions trading policies promote the green innovation activities of enterprises. Third, the impact of environmental regulations on green technology innovation is uncertain. Some studies either show that such relationship is inconsistent $[13,14]$ or point out a non-linear relationship $[15,16]$, and due to differences in their samples and indicators, these studies produce varying conclusions. Yu [17] examined resource-based companies and found an inverted U-shaped relationship between environmental regulations and corporate green technology innovation performance. Using inter-provincial data, Zhang [18] found that the impact of environmental regulations on green technological innovation has a U-shaped characteristic of initially restraining and then promoting. Wang [19] conducted an empirical analysis by using the green patent data of Chinese listed companies and confirmed the aforementioned U-shaped relationship.

In low-carbon cities, low-carbon city pilot policies are used as comprehensive environmental regulation tools, and the effect of their implementation has received much research attention. Many scholars have adopted synthetic control methods or conducted a difference-in-differences (DID) to evaluate the performance of pilot policies and found that the promotion of these policies is conducive to reducing carbon emissions [20,21], decreasing energy consumption [22], and optimizing industrial structure [23-25]. Song [26] found that carbon city construction effectively reduces urban air pollution by reducing corporate emissions and upgrading the industrial structure. Zhang [27] found that low-carbon cities reduce carbon emissions by reducing power consumption and improving technological innovation. Many scholars have also examined the performance of low-carbon cities in the development of a green economy. Wang [28] found that low-carbon pilot policies effectively promote the growth of green economies in pilot cities through the causal inference of progressive DID, whereas She [29] further pointed out that low-carbon pilot policies indirectly improve the green total factor productivity of pilot cities by promoting urban innovation and industrial upgrading.

In sum, while previous studies have analyzed the impact of environmental regulations on green technology innovation, they have mainly focused on a single environmental policy as their test object, whereas their evaluation and examination of the pilot policies in lowcarbon cities mostly relied on energy consumption as indicators. Although these indicators directly reflect the low-carbon achievements of pilot cities, they are unable to reflect the goal of urban green development. Although some scholars [28,29] have gradually paid attention to this area in recent years, only few have focused on the impact of low-carbon city construction on the green technological innovation of enterprises. Moreover, the micro-mechanism of these policies also needs to be tested. The main innovations of this 
study are as follows: (1) based on the micro perspective of enterprises, we applied a multi-period DID method to quantitatively evaluate low-carbon city pilot policies, explore their impact on green technology innovation, break through the original macro research paradigm, and expand the policy-related research; (2) on the basis of a benchmark analysis, we further tested the impact of regional heterogeneity and industry carbon intensity on the implementation of low-carbon city pilot policies and explored the direction of these policies; and (3) from the perspective of alleviating financing constraints, we analyzed the impact mechanism of low-carbon city pilot policies on corporate green technological innovation, and offered empirical support for the follow-up implementation and promotion of policies.

\section{Research Hypotheses}

As city-level environmental regulations, low-carbon city pilot policies are not strongly binding. The central government has not set specific targets for local governments in pilot cities, such as for carbon emissions and emission standards. Each pilot city has received many policy incentives and can gradually implement low-carbon work according to its regional development stage and industrial structure characteristics. The introduction of various green financial policies, such as tax incentives and government subsidies, can also guide enterprises to innovate in the field of green technology and control their greenhouse gas emissions. These pilot cities show a certain degree of freedom, but in terms of talent quality, technical foundation, market environment, and geographical location, there are great differences among the pilot areas, local governments also show certain differences in their enthusiasm and innovation in implementing low-carbon policies. These differences in turn influence the progress of related work and the effect of the final implementation. Therefore, in the context of weakly binding policies, whether the establishment of lowcarbon cities can promote enterprise innovation in the field of green technology should be tested.

\subsection{Low-Carbon City Pilot Policies and Corporate Green Technology Innovation}

Low-carbon city pilot policies are mainly implemented by reducing energy consumption and emissions in the production process, improving energy efficiency, and promoting the low-carbon transformation of industries. In this process, enterprises as the main innovation players play a vital role. The green production technology developed via scientific research innovation is key to the implementation of relevant policies. On the one hand, environmental regulations will increase the pollution control and emission reduction costs of enterprises and affect their market competitiveness. They may squeeze out these enterprises' investment in technology R\&D, change their financial investment preferences, and drive them away from reality [30]. On the other hand, as pointed out by Porter [31], environmental protection, and economic development are not mutually opposed. Reasonable environmental regulations trigger innovation compensation effects, stimulate corporate green technology innovation, and produce benefits that can make up for the environmental costs of enterprises. Following the above discussion, Hypothesis 1 is proposed as follows.

Hypothesis 1 (H1). Low-carbon city pilot policies are conducive to corporate green technological innovation.

\subsection{Low-Carbon City Pilot Policies and Regional Heterogeneity}

Prefecture-level cities in different regions often show huge differences in their market environments, resource endowments, traffic conditions, and talent supply, all of which affect their advancement of low-carbon pilot work. Therefore, some regional heterogeneity may be observed in the impact of low-carbon city pilot policies on corporate green technological innovation. Eastern cities in China are generally believed to have more obvious advantages in their accumulation of low-carbon technologies and innovative talents and in their construction of social networks [28,32]. Meanwhile, central and western cities in China not only have weak economic foundation, but also accommodate many energy-consuming 
and high-pollution enterprises, which lead to severe resource and environmental problems that require an improvement of the overall innovation environment [33]. However, previous studies also show that due to the high population concentration and large economic scale of eastern cities, their carbon lock-in effect is often stronger than that of western cities, and quickly realizing the effectiveness of low-carbon pilot policies is difficult [27]. Although many studies have examined the regional heterogeneity of low-carbon pilot policies [34], most of them have focused on urban technological innovation and carbon emissions [35]. Therefore, the impact of low-carbon pilot policies on the green technology innovation of enterprises across different regions should be examined. From the above discussion, Hypothesis 2 is proposed as follows.

Hypothesis 2 (H2). Low-carbon city pilot policies are more conducive to corporate green technological innovation in eastern cities than in central and western cities.

\subsection{Low-Carbon City Pilot Policies and Industry Carbon Intensity}

Whether companies are in high- or low-carbon emission industries, they will be affected by environmental regulations, but low-carbon emission industries have strong innovation capabilities, low environmental pollution, and high technology accumulation. Under the regulation of low-carbon city policies, high- and low-carbon companies show significant differences in their green technology innovation. Qi [12] found that compared with clean enterprises, the pilot emission trading policy has a more significant promotion effect on the green technology innovation of polluting enterprises. Shen [36] pointed out that, for different industries, environmental policies have a heterogeneous effect on the green factor productivity of enterprises. According to the policies issued by pilot cities, high-carbon emission industries are often subject to mandatory constraints due to their highenergy consumption and emissions and are strictly restricted in terms of their production capacity, emissions, and energy consumption. These restrictions not only control the entry of new enterprises and the implementation of new projects but also significantly increase the cost of environmental management. To avoid being eliminated, high-carbon emission industries will increase their investments in scientific research and improve their market competitiveness through green technology innovation. In contrast, low-carbon emission industries have received much policy support, and the cost of pollution control has not increased significantly. In addition, they have invariably attached great importance to green technology innovation. Based on the above discussion, Hypothesis 3 is proposed as follows.

Hypothesis 3 (H3). Low-carbon city policies are more conducive to green technology innovation in high-carbon emission industries than in low-carbon emission industries.

\subsection{Low-Carbon City Pilot Policies and Financing Constraints}

Innovation in the field of green technology has the characteristics of high uncertainty, large capital needs, and strong externalities. Many companies, especially listed ones, often face great financing constraints. Under the pressure of profitability, these firms pay more attention to short-term benefits, focus on their current financial statements, and lack the enthusiasm for long-term investment, which inhibit them from developing independent R\&D and collaborative innovation [37,38]. To ease the constraints in accumulating scientific research funds for enterprises and optimizing the allocation of resources among industries, low-carbon pilot cities have introduced green finance policies and provided financial support through tax incentives, government subsidies, and special funds. Many studies have pointed out that government subsidies can alleviate financing constraints [39,40] and support enterprises in their pursuit of green innovation activities [41], tax incentives reduce the financial pressure faced by these enterprises to a certain extent, promote their scientific and technological research, and improve their technology level [42-44]. However, some scholars believe that government subsidies may squeeze out enterprise $R \& D$ 
investment [45], and the subsequently triggered rent-seeking activities will reduce the incentive effect of these subsidies [46]. From the perspective of government subsidies and tax incentives, this study examines whether financing constraints can be eased to promote the implementation of low-carbon pilot policies to promote corporate green technology innovation while providing data support for future low-carbon pilot work. Based on the above discussion, Hypothesis 4 is proposed as follows.

Hypothesis 4 (H4). To implement a low-carbon city pilot policy, enterprises should promote green technological innovation by alleviating financing constraints.

\section{Methodology and Data}

\subsection{Data Sources}

Given the availability, accuracy, and relative completeness of listed company data, we used Chinese A-share listed companies as our sample and selected the green patent data of listed companies from 2005 to 2019, and the corresponding economic data at the company, industry, and city levels for an empirical analysis. At the company level, the patent data were collected from the State Intellectual Property Office of the People's Republic of China; other data were collected from the Guotaian database. At the industry level, data were obtained from the China Statistical Yearbook, and the carbon intensity of the industry was measured after processing these data. At the city level, these data were obtained from the China City Statistics Yearbook. Given that innovation in the field of green technology is mainly concentrated in the industrial sector, we mainly focused on the secondary industry and excluded the financial services and the agriculture, forestry, animal husbandry, and fishery sectors. We also excluded those enterprises with incomplete and abnormal data (including listed companies under special treatment).

Our analysis of low-carbon pilot policies covered three batches of low-carbon pilot provinces and cities (the Daxing'anling area was not included due to missing data). Given that, specific pilot work is mainly promoted in cities. Accordingly, we subdivided lowcarbon pilot provinces into prefecture-level cities and examined the overlapping areas between batches. For example, Shenyang, Zhongshan, and other cities were included in the third batch of pilot cities, but their province was included in the first batch of pilot provinces. Therefore, these cities were included in the first batch instead of the third batch. The low-carbon pilot areas examined in this research covered 102 prefecture-level cities. Given that the innovation in the field of green technology often requires a long period, the promotion effect of the pilot policy on the green technology innovation of enterprises may be relatively limited in the initial stage. Moreover, the scope of low-carbon pilots was re-expanded in 2012; the interval between the two pilots was very short. By combining the actual situation with the previous research [47], we took 2012 and 2017, when the scope of the pilot was expanded, as the time node of the pilot policy, and analyzed the promotion effect of the low-carbon city pilot policy on the green technological innovation of enterprises.

\subsection{Variable Description}

\subsubsection{Dependent Variable}

We took the number of green patent applications (lpt) of listed companies, including green invention (lpt1) and green utility (lpt2) patents, as our explained variable. On the one hand, patent technology has a long application period and may start to affect enterprise performance during the process. Therefore, the number of patent applications is highly reliable and timely [47]. On the other hand, the number of green patent applications is highly intuitive and shows that the investment of enterprises in this area is clearer than the relatively general scientific research investment. Moreover, the data of green patent applications can be classified to reflect the value connotation of innovation activities. 


\subsubsection{Core Explanatory Variable}

We set a dummy variable as our core explanatory variable that takes a value of 1 if the company's city will be included in the low-carbon city pilot list after 2012 or 2017, and takes a value of 0 otherwise.

\subsubsection{Control Variable}

We chose other factors that may affect the green technological innovation of companies at the enterprise, industry, and city levels as our control variables. (1) Enterprise maturity (lnage). The longer a company goes public, the more mature its prospect planning, goal setting, and development focus become. The company also becomes highly sensitive to policy changes and develops a strong sense of innovation. We measured this indicator by the logarithm of the number of years that the company has been listed (to avoid the influence of the number of listing years being 0 , we increased the number of listing years by 1 and took the logarithm). (2) Enterprise size (lnsize). The scale of an enterprise is closely related to its technological innovation [48]. We used the logarithm of total capital at the end of the year to measure this indicator. (3) Corporate debt (lndebt). The debt situation of enterprises reflects the evaluation of the market on the credit ability of enterprises [49]. We used the logarithm of the ratio of a company's total liabilities to its total assets at the end of the period to measure this indicator. (4) TobinQ (lnTobinQ). A larger TobinQ value corresponds to more social wealth created by an enterprise and a stronger sense of innovation. We dealt with this indicator by using a logarithm. (5) The related variables of corporate performance. Given that corporate performance and capital structure affect corporate innovation in green technology, we took corporate return on total assets (ROA), capital intensity (LNCaP), and number of employees (lnlabor) as control variables. We measured ROA by the proportion of a company's net profit in its total assets, LNCaP by the logarithm of the ratio of a company's total assets to its operating income, and lnlabor by the logarithm of the number of employees in a year. (6) City-level variables. Given that the degree of openness of cities, their industrial structure, economic status, and other environmental regulations will affect the performance of enterprises in green technology innovation [32], we controlled the use of foreign capital (lnfdigdp), industrial structure (ind), gross domestic product (GDP) per capita (lnpergdp), and other environmental regulations $\left(\operatorname{lnso}_{2}\right)$. We measured lnfdigdp by the logarithm of the actual use of foreign capital to regional GDP, ind by the proportion of the secondary industry, lnpergdp by the logarithm of regional per capita GDP, and $\mathrm{lnsO}_{2}$ by the logarithm of the proportion of regional sulfur dioxide emissions to regional GDP. Descriptive statistics of main variables are presented in Table 1.

Table 1. Summary statistics.

\begin{tabular}{cccccc}
\hline Variables & Variable Definition & Mean & SD & Min & Max \\
\hline lpt & Green patent applications & 1.538 & 11.9415 & 0.0000 & 626.0000 \\
\hline lpt1 & Green invention patent applications & 0.9676 & 8.3685 & 0.0000 & 450.0000 \\
\hline lpt2 & Green utility patent applications & 0.5709 & 4.6334 & 0.0000 & 195.0000 \\
\hline lcpilot & Dummy variable of a low-carbon city & 0.6751 & 0.4683 & 0.0000 & 1.0000 \\
\hline post & Dummy variable of the time & 0.2714 & 0.4447 & 0.0000 & 1.0000 \\
\hline lnage & Logarithm of listing age & 2.5729 & 0.4787 & 0.0000 & 3.4012 \\
\hline lnsize & Logarithm of total corporate assets & 22.2212 & 1.3738 & 16.5083 & 27.4673 \\
\hline lndebt & Logarithm of corporate debt ratio & -0.7659 & 0.5442 & -4.9510 & 4.5743 \\
\hline lnTobinQ & Logarithm of TobinQ & 0.5113 & 0.5074 & -1.8786 & 4.2436 \\
\hline ROA & Return on total assets of the enterprise & 0.0326 & 0.2743 & -8.7534 & 22.0051 \\
\hline LNCaP & Logarithm of capital intensity & 0.5484 & 0.7133 & -1.7633 & 13.5776 \\
\hline
\end{tabular}


Table 1. Cont.

\begin{tabular}{|c|c|c|c|c|c|}
\hline Variables & Variable Definition & Mean & SD & Min & $\operatorname{Max}$ \\
\hline lnlabour & Logarithm of the number of employees & 7.9903 & 1.3070 & 1.0986 & 12.2900 \\
\hline $\operatorname{lnfdigdp}$ & $\begin{array}{l}\text { The logarithm of the ratio of actually used } \\
\text { foreign capital to GDP }\end{array}$ & -5.7097 & 1.0456 & -15.5597 & -3.5101 \\
\hline ind & Proportion of secondary industry to GDP & 0.4634 & 0.1081 & 0.1814 & 0.8592 \\
\hline lnpergdp & Logarithm of GDP per capita & 10.8439 & 0.7440 & 7.8474 & 13.0557 \\
\hline $\operatorname{lnsO}_{2}$ & $\begin{array}{l}\text { The logarithm of the ratio of regional } \\
\text { sulfur dioxide emissions to GDP }\end{array}$ & 0.4308 & 1.7227 & -5.5121 & 5.6520 \\
\hline
\end{tabular}

\subsection{Model Settings}

Referring to Cheng [23] and Song [26], we used a multi-period DID model to explore the impact of low-carbon city pilot policies on corporate green technology innovation. The low-carbon pilot areas were included in the treatment group, whereas the non-pilot areas were included in the control group. The model was constructed as

$$
l p t_{i t}=\alpha_{0}+\alpha_{1} \text { lcpilot }_{r} \times \text { post }_{r t}+\alpha_{2} \sum \text { control }_{i t}+\gamma_{t}+\mu_{j}+\lambda_{r}+\xi_{i t}
$$

where $l p t_{i t}$ is the number of green patent applications of a listed company in year $\mathrm{t}$, lcpilot is the dummy variable of a low-carbon city that equals to 1 if the company's registration place is a green low-carbon pilot city and equals to 0 otherwise, and post $t_{r t}$ is a dummy variable of the time when the pilot policy was issued (given that the notices for the establishment of the second batch of pilot cities were announced on 26 November, 2012, the supporting policies could not be easily implemented in the pilot areas within the year. We set the first two batches of pilot policies to take effect in 2013 and the third batch of pilot policies to take effect in 2017). If the company is included among the first two batches of pilot areas announced after 2012, then post $t_{r t}$ takes a value of 1 . Otherwise, this variable takes a value of 0 . If this company is included among the third batch of pilot areas in or after 2017, then post $_{r t}$ takes a value of 1 and a value of 0 otherwise. In addition, Control represents the control variable, $\gamma_{t}, \mu_{j}$, and $\lambda_{r}$ control the fixed effects of time, industry, and city, respectively, $\xi_{i t}$ is a random interference item, $i, j$, and $r$ represent an enterprise, industry, and city, respectively, and $t$ represents time. In this model, the empirical analysis examined whether the coefficient of the double difference term lcpilot $_{r} \times$ post $_{r t}$ was positively significant. If $\alpha_{1}$ is significantly greater than 0 , then the low-carbon pilot policy effectively promotes the innovation of enterprises in the field of green technology.

\section{Empirical Results}

We initially performed a benchmark regression to analyze the impact of low-carbon city pilot policies on corporate green technological innovation, to test whether this policy has a promoting effect, and to conduct robustness tests based on the results.

\subsection{Benchmark Estimation Results}

This section quantitatively analyzes the impact of introducing low-carbon city pilot policies on the green technology innovation of A-share listed companies based on the benchmark model. The results are shown in Table 2, where columns (1) and (2) show the impact of the pilot policy on the number of green technology patent applications, columns (3) and (4) show the number of green invention patents, and columns (5) and (6) show the impact of the policy on green utility patents. The fixed effects of time, industry, and city were added in columns (2), (4), and (6). 
Table 2. Impact of low-carbon city pilot policies on corporate green patent applications.

\begin{tabular}{|c|c|c|c|c|c|c|}
\hline \multirow{2}{*}{ Variables } & \multicolumn{2}{|c|}{ Lpt } & \multicolumn{2}{|c|}{ Lpt1 } & \multicolumn{2}{|c|}{ Lpt2 } \\
\hline & (1) & (2) & (1) & (2) & (1) & (2) \\
\hline lcpliot $\times$ post & $\begin{array}{c}0.881 * * * \\
(0.171)\end{array}$ & $\begin{array}{c}0.679 * * * \\
(0.163)\end{array}$ & $\begin{array}{c}0.511^{* * *} \\
(0.149)\end{array}$ & $\begin{array}{c}0.449 * * * \\
(0.007)\end{array}$ & $\begin{array}{c}0.370 * * * \\
(0.101)\end{array}$ & $\begin{array}{c}0.229 * * \\
(0.083)\end{array}$ \\
\hline lndebt & $\begin{array}{l}0.239 * \\
(0.129)\end{array}$ & $\begin{array}{c}0.329^{* * *} \\
(0.165)\end{array}$ & $\begin{array}{c}0.220 * * * \\
(0.071)\end{array}$ & $\begin{array}{c}0.282^{* * *} \\
(0.053)\end{array}$ & $\begin{array}{c}0.018 \\
(0.075)\end{array}$ & $\begin{array}{l}0.047^{*} \\
(0.150)\end{array}$ \\
\hline lnsize & $\begin{array}{c}1.608^{* * *} \\
(0.519)\end{array}$ & $\begin{array}{c}0.564^{* *} \\
(0.067)\end{array}$ & $\begin{array}{c}1.000^{* *} \\
(0.356)\end{array}$ & $\begin{array}{c}0.420 \text { ** } \\
(0.043)\end{array}$ & $\begin{array}{c}0.608^{* * *} \\
(0.176)\end{array}$ & $\begin{array}{c}0.144^{* * *} \\
(0.030)\end{array}$ \\
\hline ROA & $\begin{array}{l}-0.142 \\
(0.232)\end{array}$ & $\begin{array}{c}0.078 \\
(0.110)\end{array}$ & $\begin{array}{l}-0.063 \\
(0.146)\end{array}$ & $\begin{array}{c}0.096 \\
(0.055)\end{array}$ & $\begin{array}{l}-0.080 \\
(0.095)\end{array}$ & $\begin{array}{l}-0.018 \\
(0.056)\end{array}$ \\
\hline $\ln$ TobinQ & $\begin{array}{l}1.682 * \\
(0.793)\end{array}$ & $\begin{array}{c}0.340 \\
(0.196)\end{array}$ & $\begin{array}{l}1.056^{*} \\
(0.539)\end{array}$ & $\begin{array}{c}0.256 \\
(0.160)\end{array}$ & $\begin{array}{c}0.626^{* *} \\
(0.268)\end{array}$ & $\begin{array}{c}0.084 \\
(0.056)\end{array}$ \\
\hline LNCaP & $\begin{array}{c}0.087 \\
(0.110)\end{array}$ & $\begin{array}{c}0.421^{* * *} \\
(0.109)\end{array}$ & $\begin{array}{c}0.011 \\
(0.085)\end{array}$ & $\begin{array}{l}0.233 \text { ** } \\
(0.096)\end{array}$ & $\begin{array}{c}0.077 \\
(0.079)\end{array}$ & $\begin{array}{c}0.188^{* * *} \\
(0.032)\end{array}$ \\
\hline lnlabour & $\begin{array}{l}0.599 * * \\
(0.224)\end{array}$ & $\begin{array}{c}0.434^{* * *} \\
(0.099)\end{array}$ & $\begin{array}{l}0.452^{* *} \\
(0.177)\end{array}$ & $\begin{array}{c}0.322^{* * *} \\
(0.077)\end{array}$ & $\begin{array}{c}0.147^{* *} \\
(0.050)\end{array}$ & $\begin{array}{c}0.112^{* * *} \\
(0.028)\end{array}$ \\
\hline lnage & $\begin{array}{c}-0.684 * \\
(0.356)\end{array}$ & $\begin{array}{c}-0.878^{* * *} \\
(0.129)\end{array}$ & $\begin{array}{c}-0.551 * \\
(0.301)\end{array}$ & $\begin{array}{c}-0.452^{* * *} \\
(0.093)\end{array}$ & $\begin{array}{l}-0.133 \\
(0.077)\end{array}$ & $\begin{array}{c}-0.426^{* * *} \\
(0.081)\end{array}$ \\
\hline ind & $\begin{array}{c}2.345 \\
(1.785)\end{array}$ & $\begin{array}{c}2.753^{* * * *} \\
(0.820)\end{array}$ & $\begin{array}{c}1.880 \\
(1.249)\end{array}$ & $\begin{array}{c}2.255^{* * *} \\
(0.615)\end{array}$ & $\begin{array}{c}0.465 \\
(0.573)\end{array}$ & $\begin{array}{c}0.498^{* * *} \\
(0.347)\end{array}$ \\
\hline lnfdigdp & $\begin{array}{c}0.353 * * * \\
(0.116)\end{array}$ & $\begin{array}{c}0.143 * * * \\
(0.007)\end{array}$ & $\begin{array}{c}0.199 * * \\
(0.086)\end{array}$ & $\begin{array}{l}0.101^{* *} \\
(0.006)\end{array}$ & $\begin{array}{c}0.154^{* * *} \\
(0.042)\end{array}$ & $\begin{array}{c}0.042 * * * \\
(0.002)\end{array}$ \\
\hline lnpergdp & $\begin{array}{l}-0.178 \\
(0.271)\end{array}$ & $\begin{array}{l}-1.052 \\
(0.164)\end{array}$ & $\begin{array}{l}-0.118 \\
(0.168)\end{array}$ & $\begin{array}{l}-0.644 \\
(0.159)\end{array}$ & $\begin{array}{l}-0.060 \\
(0.130)\end{array}$ & $\begin{array}{l}-0.408 \\
(0.050)\end{array}$ \\
\hline $\operatorname{lnsO_{2}}$ & $\begin{array}{l}-0.114 \\
(0.187)\end{array}$ & $\begin{array}{l}-0.060 \\
(0.078)\end{array}$ & $\begin{array}{l}-0.199 \\
(0.137)\end{array}$ & $\begin{array}{c}-0.100 * \\
(0.051)\end{array}$ & $\begin{array}{c}0.086 \\
(0.061)\end{array}$ & $\begin{array}{c}0.040 \\
(0.031)\end{array}$ \\
\hline constant & $\begin{array}{c}-35.278^{* * *} \\
(10.679)\end{array}$ & $\begin{array}{c}-3.514 * * \\
(0.992)\end{array}$ & $\begin{array}{c}-22.337^{* *} \\
(7.674)\end{array}$ & $\begin{array}{c}-4.377^{* *} \\
(1.515)\end{array}$ & $\begin{array}{c}-12.941 * * * \\
(3.116)\end{array}$ & $\begin{array}{c}0.866 \\
(1.008)\end{array}$ \\
\hline Time fixed effect & NO & YES & NO & YES & $\mathrm{NO}$ & YES \\
\hline Industry fixed effect & $\mathrm{NO}$ & YES & $\mathrm{NO}$ & YES & $\mathrm{NO}$ & YES \\
\hline Urban fixed effect & NO & YES & NO & YES & NO & YES \\
\hline $\mathrm{N}$ & 10,080 & 10,080 & 10,080 & 10,080 & 10,080 & 10,080 \\
\hline Adj R2 & 0.050 & 0.032 & 0.047 & 0.029 & 0.037 & 0.026 \\
\hline
\end{tabular}

Note: figures in () are robust standard error; ${ }^{* * *}{ }^{* *}$ and ${ }^{*}$ indicate significance at the $1 \%, 5 \%$, and $10 \%$ levels, respectively.

The regression results in Table 2 reveal that the coefficient of lcpliot $\times$ post is significantly positive and remains significant at the $1 \%$ level after controlling for the fixed effect, thereby suggesting that the pilot policy of low-carbon cities effectively promotes the innovation of enterprises in green technology. After the introduction of the pilot policy, the number of green patent applications of listed enterprises in the industrial sector significantly increased, especially for green invention patents, thereby supporting Hypothesis 1 , which posits that the pilot low-carbon city policy is conducive to enterprise green technology innovation. On the one hand, given that the pilot policy focuses on the industry, construction, and other sectors, under the requirements of low-carbon development, the emission cost of relevant enterprises increases, their energy conservation and emission reduction incentives gradually increase, and their enthusiasm for green technology innovation is improved. On the other hand, given the weak constraint of the pilot policy, the pilot cities can flexibly promote their work according to their actual situation and explore the win-win path of emission reduction and economic growth. The cost pressures faced by enterprises related to pollution control and emission reduction will be controlled within a relatively reasonable range to avoid crowding out investments in $R \& D$ and innovation. In terms of control variables, the increase in debt, scale, ratio of market value to replacement value, capital intensity, number of employees, use of urban foreign capital, and industrial 
structure all triggered an increase in green patent applications to a certain extent, which was consistent with our expectations during our selection of variables. However, enterprise maturity showed a negative impact on green technology innovation. Specifically, the longer an enterprise goes public, the weaker its innovation enthusiasm becomes. The investment behavior of an enterprise may be constrained by financing capital after going public, which may drive this enterprise to focus on its current profit and enhance its dependence on its current development path.

\subsection{Parallel Trend Test}

In the above empirical analysis, we preliminarily evaluated the promotion effect of low-carbon city pilot policies on corporate green technological innovation. Given that meeting the parallel trends assumption is an important prerequisite for the use of multiperiod DID, we followed the practice of Song [26] and constructed our model as

$$
l p t_{i t}=\alpha_{0}+\sum_{k=-5}^{5} \beta_{k} \times Z_{r, t_{0}+k}+\alpha_{1} \sum \text { control }_{i t}+\gamma_{t}+\mu_{j}+\lambda_{r}+\xi_{i t}
$$

where $t_{0}$ represents the time when the low-carbon pilot policy was introduced, $\mathrm{K}$ represents the $\mathrm{k}$-th year after the policy was introduced, and $Z_{r, t_{0}+k}$ are dummy variables indicating the $\mathrm{k}$-th year after the city $r$ was included in the low-carbon city pilot scope (the value range of $\mathrm{K}$ is $[-5,5]$, which covers the 5 years before and after the policy, was issued. If the time exceeds five years, then it is still set to five years in the model). Meanwhile, the estimated coefficient $\beta_{K}$ reflects the difference in the number of green patent applications between the processing and control groups $\mathrm{K}$ years after the introduction of the pilot policy. When $\mathrm{k}$ is less than 0 (before the introduction of the policy) if the trend of $\beta_{K}$ is stable and fluctuates around 0 , then the parallel trend hypothesis is satisfied. Otherwise, a significant difference is observed between the two groups before the introduction of the pilot policy, thereby rejecting our hypothesis. The test results are shown in Figure 1. We took the previous period of the policy as the benchmark group, the vertical axis as the dynamic effect of the policy (represented by the value of $\beta_{K}$ ), and the horizontal axis as the time of the policy. Figure 1 shows that before the introduction of the pilot policy for low-carbon cities, $\beta_{K}$ fluctuates around 0 , thereby indicating no significant differences between the treatment and control groups before the introduction of the policy. This finding is comparable and conforms to the parallel trend hypothesis. Specifically, in the year when the policy was issued and several years after, $\beta_{K}$ remained positive and significant. Despite the large fluctuation in the second and third years, the overall trend was still on the rise, thereby suggesting that the pilot policy of low-carbon cities increased the number of green patent applications of enterprises and that such promotion effect was gradually enhanced.

\subsection{Robustness Test}

\subsubsection{PSM-DID}

To avoid the sample self-selection problem caused by systematic differences, we adopted the double differential propensity score matching method (PSM-DID) for the robustness test. According to the balance test results in Table 3, the standardized deviation of most covariates after nearest neighbor matching was less than $10 \%$, and the original hypothesis that there is no systematic deviation between the treatment and control groups was supported. On this basis, we performed a multi-period double difference estimation and reported the results in Table 4 . The coefficient of lcpilot $\times$ post remained positive and significant, thereby suggesting that through the robustness test, the pilot policy of low-carbon cities can promote the green technology innovation of enterprises. This result was also in line with the empirical findings of the benchmark regression. 


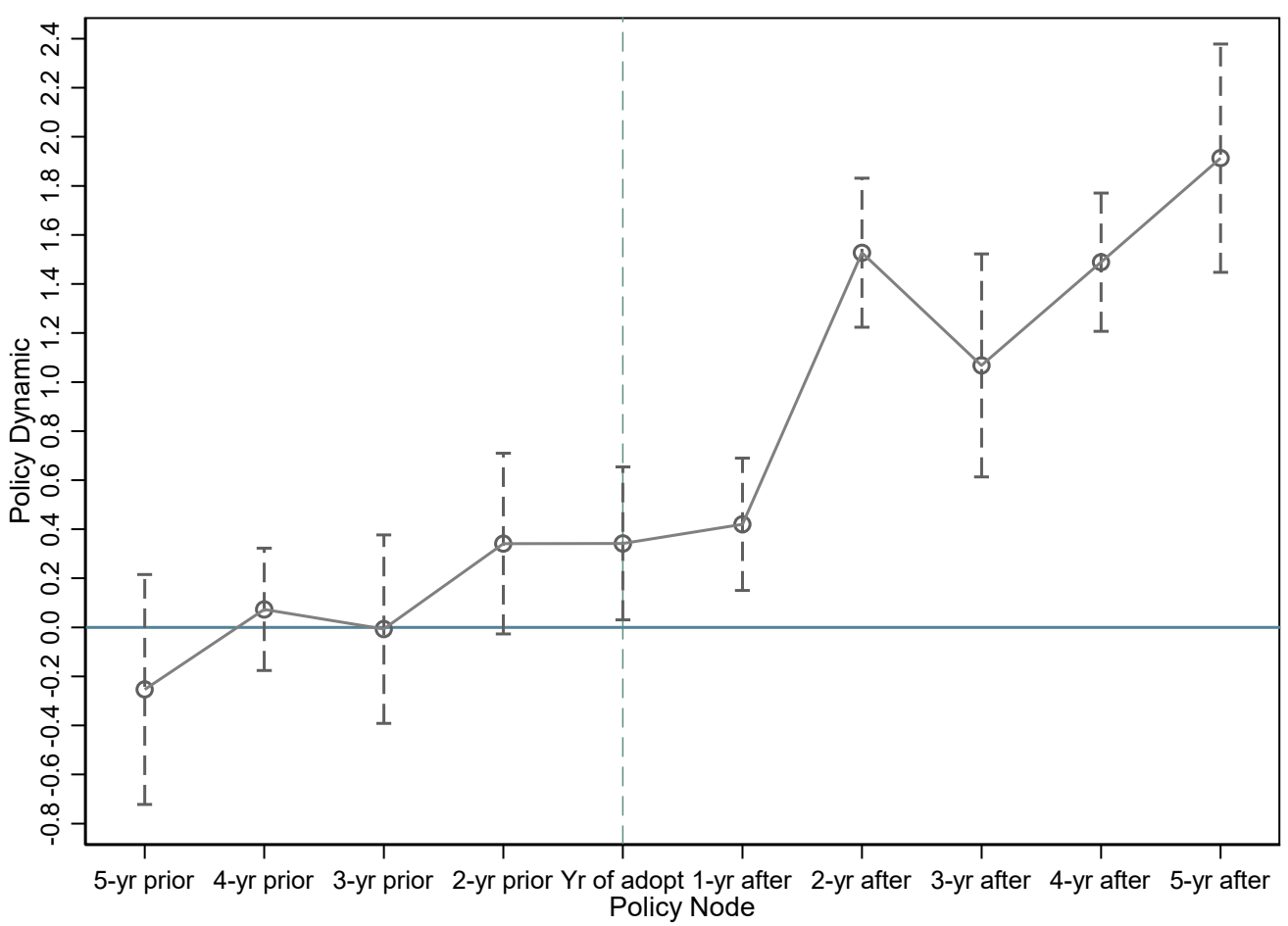

Figure 1. Parallel trend test results.

Table 3. Propensity score matching method-difference-in-differences (PSM-DID) balance test results.

\begin{tabular}{|c|c|c|c|c|c|c|}
\hline \multirow{2}{*}{\multicolumn{2}{|c|}{ Variables }} & \multicolumn{2}{|c|}{ Mean } & \multirow{3}{*}{$\begin{array}{c}\mathrm{SD} / \% \\
-12.9\end{array}$} & \multicolumn{2}{|c|}{ T-Test } \\
\hline & & \multirow{2}{*}{$\begin{array}{c}\text { Treat } \\
-0.8177\end{array}$} & \multirow{2}{*}{$\begin{array}{c}\text { Control } \\
-0.7483\end{array}$} & & \multirow{2}{*}{$\frac{T}{-5.76}$} & \multirow{2}{*}{$\begin{array}{r}p>\mid \mathbf{t} \\
0.000\end{array}$} \\
\hline lo & $\mathrm{U}$ & & & & & \\
\hline Inaed & M & -0.8025 & -0.8199 & 3.2 & 1.09 & 0.278 \\
\hline \multirow{2}{*}{ lnage } & $\mathrm{U}$ & 2.9128 & 2.4449 & 123.2 & 28.10 & 0.000 \\
\hline & M & 2.8865 & 2.8920 & -1.5 & -0.79 & 0.432 \\
\hline \multirow{2}{*}{ ROA } & $\mathrm{U}$ & 0.0373 & 0.0302 & 3.0 & 1.15 & 0.250 \\
\hline & $\mathrm{M}$ & 0.0367 & 0.0585 & -9.2 & -1.53 & 0.125 \\
\hline \multirow{2}{*}{ lnsize } & $\mathrm{U}$ & 22.8380 & 22.0160 & 61.9 & 27.76 & 0.000 \\
\hline & $\mathrm{M}$ & 22.7490 & 22.6080 & 10.6 & 1.62 & 0.112 \\
\hline \multirow{2}{*}{$\ln$ TobinQ } & $\mathrm{U}$ & 0.5221 & 0.5056 & 3.3 & 1.45 & 0.146 \\
\hline & M & 0.5383 & 0.5182 & 4.0 & 1.31 & 0.190 \\
\hline \multirow{2}{*}{ lnfdigdp } & $\mathrm{U}$ & -5.5682 & -5.7659 & 19.5 & 8.42 & 0.000 \\
\hline & M & -5.6442 & -6.1207 & 46.9 & 10.91 & 0.000 \\
\hline \multirow{2}{*}{ lnpergdp } & $\mathrm{U}$ & 11.4470 & 10.6250 & 136.9 & 56.47 & 0.000 \\
\hline & $M$ & 11.3220 & 11.2290 & 15.6 & 6.34 & 0.000 \\
\hline \multirow{2}{*}{ LNCaP } & $\mathrm{U}$ & 0.5834 & 0.5283 & 7.9 & 3.48 & 0.001 \\
\hline & $\mathrm{M}$ & 0.5770 & 0.5661 & 1.6 & 0.53 & 0.595 \\
\hline \multirow{2}{*}{ lnlabour } & $\mathrm{U}$ & 8.2002 & 7.9290 & 20.9 & 9.31 & 0.000 \\
\hline & $\mathrm{M}$ & 8.1869 & 8.1295 & 4.4 & 1.50 & 0.134 \\
\hline \multirow{2}{*}{ ind } & $\mathrm{U}$ & 0.3969 & 0.4883 & -87.9 & -40.53 & 0.000 \\
\hline & $\mathrm{M}$ & 0.4264 & 0.4299 & -3.4 & -1.08 & 0.281 \\
\hline \multirow{2}{*}{$\operatorname{lnsO_{2}}$} & $\mathrm{U}$ & -1.2446 & 1.0463 & -152.4 & -73.26 & 0.000 \\
\hline & $\mathrm{M}$ & -0.5973 & -0.5601 & -2.5 & -0.99 & 0.324 \\
\hline
\end{tabular}

Note: U denotes before matching, whereas M denotes after matching. 
Table 4. PSM-DID robustness test.

\begin{tabular}{ccccccc}
\hline \multirow{2}{*}{ Variables } & \multicolumn{2}{c}{ Lpt } & \multicolumn{2}{c}{ Lpt1 } & \multicolumn{2}{c}{ Lpt2 } \\
\cline { 2 - 7 } & $\mathbf{( 1 )}$ & $\mathbf{( 2 )}$ & $\mathbf{( 3 )}$ & $\mathbf{( 4 )}$ & $\mathbf{( 5 )}$ & $\mathbf{( 6 )}$ \\
\hline \multirow{2}{*}{ lcpilot $\times$ post } & $0.470^{* * *}$ & $0.683^{* * *}$ & $0.253^{* * *}$ & $0.410^{* * *}$ & $0.217^{* *}$ & $0.273^{* *}$ \\
& $(0.137)$ & $(0.145)$ & $(0.068)$ & $(0.069)$ & $(0.079)$ & $(0.091)$ \\
\hline Control & NO & YES & NO & YES & NO & YES \\
\hline Time fixed effect & YES & YES & YES & YES & YES & YES \\
\hline Industry fixed effect & YES & YES & YES & YES & YES & YES \\
\hline Urban fixed effect & YES & YES & YES & YES & YES & YES \\
\hline $\mathrm{N}$ & 7625 & 7625 & 7625 & 7625 & 7625 & 7625 \\
\hline Adj R2 & 0.087 & 0.126 & 0.086 & 0.124 & 0.082 & 0.116 \\
\hline
\end{tabular}

Note: figures in () are robust standard error; ${ }^{* * *},{ }^{* *}$ indicate significance at the $1 \%, 5 \%$ levels, respectively.

\subsubsection{Replace Dependent Variables}

To eliminate other unobservable factors that interfere with the conclusions of the regression model, we used the index of the proportion of green patent applications in all patent applications in a specific year to test the robustness [50], to reflect the importance of enterprises in green technology innovation, and to further highlight the impact of the low-carbon city pilot policy. The regression results are shown in Table 5, where ralpt, ralpt1, and ralpt 2 denote the proportion of green patents, green invention patents, and green utility patents, respectively. According to the regression results, the coefficients of lcpilot $\times$ post were positively significant, suggesting that the introduction of the low-carbon city pilot policy promotes the green technology innovation of enterprises, improves their attention, and proves the robustness of the benchmark regression results. Moreover, the partial coefficient of double difference in column (4) was significantly larger than that in column (6), thereby suggesting that the promotion effect of the low-carbon city pilot policy on enterprise green technology innovation is mainly reflected in green invention patents with high scientific and technological content.

Table 5. Impact of low-carbon city pilot policies on the proportion of green patent applications.

\begin{tabular}{ccccccc}
\hline \multirow{2}{*}{ Variables } & \multicolumn{2}{c}{ Ralpt } & \multicolumn{2}{c}{ Ralpt1 } & \multicolumn{2}{c}{ Ralpt2 } \\
\cline { 2 - 7 } & $\mathbf{( 1 )}$ & $\mathbf{( 2 )}$ & $\mathbf{( 3 )}$ & $\mathbf{( 4 )}$ & $\mathbf{( 5 )}$ & $\mathbf{( 6 )}$ \\
\hline \multirow{2}{*}{ lcpilot $\times$ post } & $0.006^{* * *}$ & $0.006^{* * *}$ & $0.006^{* * *}$ & $0.005^{* * *}$ & $0.002^{* *}$ & $0.001^{* *}$ \\
& $(0.003)$ & $(0.002)$ & $(0.002)$ & $(0.001)$ & $(0.001)$ & $(0.000)$ \\
\hline Control & YES & YES & YES & YES & YES & YES \\
\hline Time fixed effect & NO & YES & NO & YES & NO & YES \\
\hline Industry fixed effect & NO & YES & NO & YES & NO & YES \\
\hline Urban fixed effect & NO & YES & NO & YES & NO & YES \\
\hline N & 10,080 & 10,080 & 10,080 & 10,080 & 10,080 & 10,080 \\
\hline Adj R2 & 0.025 & 0.035 & 0.027 & 0.036 & 0.024 & 0.032 \\
\hline
\end{tabular}

Note: figures in () are robust standard error; ${ }^{* * *},{ }^{* *}$ indicate significance at the $1 \%, 5 \%$ levels, respectively.

\subsection{Heterogeneity Analysis}

\subsubsection{Heterogeneity Test Based on Region}

Chinese regions show huge differences in their economic conditions, resource endowments, and business environments. Although the inherent location and environmental deficiencies of the central and western regions have been filled through the continuous advancement of infrastructure construction and the forging of new fulcrums for development, a considerable gap can still be observed among the eastern, central, and western cities, which will influence their investment activities, such as enterprise R\&D and innovation. Accordingly, we examined the geographical distribution of enterprises and divided our sample into eastern, central, and western cities based on the division of national policies. 
Following Wang [28] and Xiong [34], we introduce regional dummy variables into model (1) to explore whether low-carbon city pilot policies have a heterogeneous impact on the green technology innovation of enterprises across different regions. The model was constructed as

$$
\text { lpt }_{i t}=\beta_{0}+\beta_{1} \text { lcpilot }_{r} \times \text { post }_{r t} \times \text { location }+\beta_{2} \sum \text { control }_{i t}+\gamma_{t}+\mu_{j}+\lambda_{r}+\xi_{i t}
$$

where location represents the location of the city where the company belongs (i.e., east, middle, and west). While examining the effect of low-carbon pilot policies on the green technological innovation of enterprises in eastern cities, we set east, middle, and west to 1 , 0 , and 0 , respectively; similarly, while investigating central cities (western cities), we set middle (west) to 1 , and the rest was set to 0 .

The regression results are shown in Table 6. The coefficients in columns (1) and (4) were positively significant at the 5\% level, thereby indicating that with the gradual implementation of the low-carbon pilot policy, enterprises in eastern cities begin to focus on green technology innovation, which increases not only the number, but also the proportion of green patent applications. However, the coefficients in columns (2) and (3) were not significant, indicating that the promotion effect of the low-carbon pilot policy on the green technology innovation of enterprises in central and western cities was not obvious. Although significant, the coefficient in column (6) only reflected the relative level of green innovation, thereby supporting Hypothesis 2. Specifically, the pilot policy of low-carbon cities was more conducive to the enterprise green technology innovation of eastern cities than to those of the central and western cities. On the one hand, because of the objective differences in the economic structure of the eastern, central, and western cities, traditional industries are mainly concentrated in the central and western cities, limited by their regional economy and traditional development path, enterprises in central and western cities face more difficulties in their attempts to transform and upgrade themselves and have a relatively weak innovation enthusiasm compared with their counterparts in eastern cities. On the other hand, some differences can be observed in the governance capacity of regional governments. The ability of some pilot cities to explore regional development mode needs to be improved, and they cannot utilize the low-carbon pilot policy to guide enterprises to explore green technology innovation.

Table 6. Heterogeneity analysis of region.

\begin{tabular}{|c|c|c|c|c|c|c|}
\hline \multirow{2}{*}{ Variables } & \multicolumn{3}{|c|}{ Lpt } & \multicolumn{3}{|c|}{ Ralpt } \\
\hline & (1) & (2) & (3) & (4) & (5) & (6) \\
\hline lcpilot $\times$ post $\times$ east & $\begin{array}{c}0.125 * * \\
(0.050)\end{array}$ & & & $\begin{array}{c}0.004^{* *} \\
(0.001)\end{array}$ & & \\
\hline lcpilot $\times$ post $\times$ middle & & $\begin{array}{c}0.012 \\
(0.075)\end{array}$ & & & $\begin{array}{c}0.010 \\
(0.005)\end{array}$ & \\
\hline lcpilot $\times$ post $\times$ west & & & $\begin{array}{c}0.019 \\
(0.047)\end{array}$ & & & $\begin{array}{c}0.012^{* * *} \\
(0.003)\end{array}$ \\
\hline Control & YES & YES & YES & YES & YES & YES \\
\hline $\mathrm{N}$ & 10,080 & 10,080 & 10,080 & 10,080 & 10,080 & 10,080 \\
\hline AdjR2 & 0.053 & 0.053 & 0.053 & 0.016 & 0.016 & 0.017 \\
\hline
\end{tabular}

Note: figures in () are robust standard error; ${ }^{* * *},{ }^{* *}$ indicate significance at the $1 \%, 5 \%$ levels, respectively.

\subsubsection{Heterogeneity Test Based on Industry Carbon Emissions}

The energy conservation, emission reduction, and green technology innovation of high carbon emission industries play key roles in implementing low-carbon pilot work and promoting the development of a low-carbon economy. As an important focus of carbon emission control, high carbon emission industries are often subject to many constraints, and relevant enterprises develop a strong response to the pilot policy of low-carbon cities and actively increase their R\&D investments to promote innovation in the field of green technology. To test this hypothesis and further explore the effectiveness of the slow-carbon city 
pilot policy, we introduced industry carbon intensity $\left(\mathrm{CO}_{2}\right)$ into model $(1)$ and constructed a triple difference model as shown in model (4). Industry carbon intensity denotes the ratio of industry carbon emissions and operating income. The carbon emission coefficient refers to the "General Principles of Comprehensive Energy Consumption Calculation" (GB/T 2589-2008) and "Provincial Greenhouse Gas Inventory Compilation Guide" (Fagaiban Climate (2011) No. 1041). We focused on the coefficient of the triple difference sub item lcpilot $\times$ post $\times \mathrm{CO}_{2}$. If this coefficient is less than 0 , then the pilot policy has a stronger role in promoting green technology innovation in low-carbon emission industries than in high-carbon emission industries. Otherwise, high-carbon emission industries are the main objects of the policy-induced green technology innovation.

$$
\begin{aligned}
\text { lpt }_{i t}=\beta_{0}+ & \beta_{1} \text { lcpilot }_{r} \times \text { post }_{r t} \times \text { co }_{2}+\beta_{2} \text { lcpilot }_{r} \times \text { post }_{r t}+\beta_{3} \text { lcpilot }_{r} \times \text { co }_{2} \\
& +\beta_{4} \text { post }_{r t} \times \mathrm{co}_{2}+\beta_{5} \sum \text { control }_{i t}+\gamma_{t}+\mu_{j}+\lambda_{r}+\xi_{i t}
\end{aligned}
$$

The regression results are shown in Table 7 . The lcpilot $\times$ post $\times \mathrm{CO}_{2}$ coefficients were significantly positive at the $1 \%$ level, thereby suggesting that the pilot policy plays a key role in promoting green technology innovation in high carbon emission industries. To achieve the peak goal of carbon emissions and control the amount of carbon emissions, the local government took the regulation of high carbon emission industries as its starting point and encouraged the relevant enterprises to increase their investment in green technology $R \& D$ to meet social development needs. This finding echoed those of $\mathrm{Xu}$ [47] and Sheng [51], and verified Hypothesis 3 .

Table 7. Heterogeneity analysis of industry carbon emissions.

\begin{tabular}{ccccccc}
\hline Variables & Lpt & Lpt1 & Lpt2 & Ralpt & Ralpt1 & Ralpt2 \\
\cline { 2 - 7 } & $\mathbf{( 1 )}$ & $\mathbf{( 2 )}$ & $\mathbf{( 3 )}$ & $\mathbf{( 4 )}$ & $\mathbf{( 5 )}$ & $\mathbf{( 6 )}$ \\
\hline \multirow{2}{*}{ lcpilot $\times$ post $\times \mathrm{co}_{2}$} & $\begin{array}{c}\text { (3).763** } \\
(0.204)\end{array}$ & $\begin{array}{c}0.348^{* * *} \\
(0.074)\end{array}$ & $\begin{array}{c}0.295^{* * *} \\
(0.581)\end{array}$ & $\begin{array}{c}0.022^{* * *} \\
(0.002)\end{array}$ & $\begin{array}{c}0.010^{* * *} \\
(0.002)\end{array}$ & $\begin{array}{c}0.012^{* * *} \\
(0.001)\end{array}$ \\
\hline lcpilot $\times$ post & 0.042 & 0.006 & 0.037 & 0.001 & 0.001 & 0.000 \\
Control & $(0.032)$ & $(0.017)$ & $(0.063)$ & $(0.002)$ & $(0.001)$ & $(0.000)$ \\
\hline Time fixed effect & YES & YES & YES & YES & YES & YES \\
\hline Industry fixed effect & YES & YES & YES & YES & YES & YES \\
\hline Urban fixed effect & YES & YES & YES & YES & YES & YES \\
\hline N & 9886 & 9886 & 9886 & 9886 & 9886 & 9886 \\
\hline Adj 2 & 0.054 & 0.045 & 0.018 & 0.024 & 0.019 & 0.023 \\
\hline
\end{tabular}

Note: figures in () are robust standard error; ${ }^{* * *}$ indicate significance at the $1 \%$ levels, respectively.

\subsection{Mechanism Analysis}

The above empirical test results show that the pilot policy of low-carbon cities can promote the green technology innovation of enterprises, especially those in eastern cities, which belong to high carbon emission industries. To discuss the effectiveness of this policy, we further analyzed its mechanism for easing financing constraints. Compared with traditional technology innovation, green technology innovation focuses on protecting the ecological environment, and coordinating and unifying economic and ecological benefits. However, green technology R\&D has high uncertainty and positive externality, while enterprises have relatively low enthusiasm and face huge constraints in accumulating $R \& D$ funds. To implement low-carbon pilot work, the government requires financial support. We therefore analyzed the mechanism of the low-carbon city pilot policy from the perspective of easing financing constraints and tested whether such policy can promote the innovation of enterprises in green technology through tax incentives and government subsidies. The triple difference model is shown in models (5) and (6), where tax denotes tax incentives, whereas $\ln s u b$ denotes government subsidies (tax is computed as "tax refund received/(tax 
refund received + various taxes paid)," and lnsub is the logarithm of government subsidies. The data were collected from the Guotaian database).

$$
\begin{aligned}
\text { lpt }_{i t}= & \beta_{0}+\beta_{1} \text { lcpilot }_{r} \times \text { post }_{r t} \times \text { tax }+\beta_{2} \text { lcpilot }_{r} \times \text { post }_{r t}+\beta_{3} \text { lcpilot }_{r} \times \\
& \text { tax }+\beta_{4} \text { post }_{r t} \times \operatorname{tax}+\beta_{5} \sum \text { control }_{i t}+\gamma_{t}+\mu_{j}+\lambda_{r}+\xi_{i t} \\
\text { lpt }_{i t}=\beta_{0}+ & \beta_{1} \text { lcpilot }_{r} \times \text { post }_{r t} \times \text { lnsub }+\beta_{2} \text { lcpilot }_{r} \times \text { post }_{r t}+\beta_{3} \text { lcpilot }_{r} \times \operatorname{lnsub} \\
& +\beta_{4} \text { post }_{r t} \times \text { lnsub }+\beta_{5} \sum \text { control }_{i t}+\gamma_{t}+\mu_{j}+\lambda_{r}+\xi_{i t}
\end{aligned}
$$

The empirical results are shown in Table 8 . The triple difference partial coefficients in columns (1) to (4) were positively significant, whereas those in columns (5) and (6) were not significant. These results suggest that the pilot policy of low-carbon cities alleviates the financing constraints of enterprises through tax incentives and government subsidies and encourages them to carry out green technology innovation as reflected in their application of green invention patents. Although the promotion effect on their application of green practical patents is relatively not obvious, it does not affect the verification of Hypothesis 4, especially considering that the innovation level of green invention patents is higher than that of utility patents. Thereby supporting Hypothesis 4. Columns (1) to (4) also show that the size and significance level of the partial coefficients of triple difference in model (5) are significantly higher than that in model (6), which may be ascribed to the fact that tax preference plays an effective role through an open and transparent market mechanism while reducing direct intervention in enterprises. In this case, enterprises can give full play to their subjective ability to optimize their allocation of resources based on their current situation. As a direct incentive measure, government subsidies often have strict control, which hinders enterprises from making adjustments according to their actual situation. In addition, given the strong planning of government subsidies and limited by incomplete information, the ability of competent departments, and the intervention of interest groups, some problems may emerge, such as blind subsidies for enterprises with poor performance and blind construction of high-tech projects.

Table 8. Mechanism analysis of the low carbon city pilot policy.

\begin{tabular}{ccccccc}
\hline \multirow{2}{*}{ Variables } & \multicolumn{2}{c}{ Lpt } & \multicolumn{2}{c}{ Lpt1 } & \multicolumn{2}{c}{ Lpt2 } \\
\cline { 2 - 7 } & $\mathbf{( 1 )}$ & $\mathbf{( 2 )}$ & $\mathbf{( 3 )}$ & $\mathbf{( 4 )}$ & $\mathbf{( 5 )}$ & $\mathbf{( 6 )}$ \\
\hline \multirow{2}{*}{ lcpilot $\times$ post } & -0.148 & -0.139 & $-0.341^{* * *}$ & -0.310 & $0.192^{* * *}$ & 0.028 \\
& $(0.120)$ & $(0.166)$ & $(0.073)$ & $(0.315)$ & $(0.064)$ & $(0.028)$ \\
\hline \multirow{2}{*}{ lcpilot $\times$ post $\times$ tax } & $6.428^{* * *}$ & & $6.157^{* * *}$ & & 0.270 \\
& $(1.019)$ & & $(0.812)$ & & $(0.239)$ \\
\hline \multirow{2}{*}{ lcpilot $\times$ post $\times$ lnsub } & & $0.017^{*}$ & & $0.051^{*}$ & & 0.002 \\
\hline Control & YES & YES & YES & YES & YES & YES \\
\hline Time fixed effect & YES & YES & YES & YES & YES & YES \\
\hline Industry fixed effect & YES & YES & YES & YES & YES & YES \\
\hline Urban fixed effect & YES & YES & YES & YES & YES & YES \\
\hline $\mathrm{N}$ & 9904 & 9904 & 9904 & 9904 & 9904 & 9904 \\
\hline AdjR2 & 0.024 & 0.022 & 0.025 & 0.020 & 0.016 & 0.016 \\
\hline
\end{tabular}

Note: Figures in () are robust standard error; ${ }^{* * *},{ }^{*}$ indicate significance at the $1 \%, 10 \%$ levels, respectively.

\section{Discussion}

To cope with climate change and achieve sustainable development, green and lowcarbon economy has become a new focus in China. However, the industrial sector still dominates the industrial structure of most cities in China, and this sector's energy structure is mainly concentrated in high-carbon energy. Many challenges are involved in the process of low-carbon development, which necessitate the market to play its key role in stimulating the green innovation vitality of enterprises. We constructed a multi-period 
double difference model to study the impact of the low-carbon city pilot policy on the green technology innovation of enterprises. Our research contributes to the literature in two important aspects. First, we expand the relevant literature on the low-carbon city pilot policy. Previous studies have often focused on the industry or city level [22-28] and tested industrial structure [23-25], carbon emissions [22,27], and other indicators yet largely ignored the impact of low-carbon city construction from the perspective of enterprises. Although some scholars [34,47] have examined this aspect in recent years, most of the sample data included only the first two batches of pilot cities. We used multi-phase DID to include three batches of pilot cities within our empirical scope and found that the pilot policy of low-carbon cities promotes the green technology innovation of enterprises and increases the number and proportion of their green patent applications, which may be ascribed to the emphasis of this policy on industrial sectors and its weak constraints. Enterprises are encouraged by innovation and avoid crowding out their R\&D investments due to high pollution control cost. Second, we clarified the role and impact mechanism of low-carbon pilot policy, and found that the introduction of the pilot policy was highly conducive to the green technology innovation of enterprises in eastern cities and high carbon emission industries. By further analyzing the mechanism of the pilot policy in easing financing constraints, we found that tax incentives and government subsidies help this policy play its role in green technology innovation. Moreover, tax preference has a stronger promotion effect compared with government subsidies probably because the former exerts its effect through the market mechanism. In addition, enterprises have a strong subjective initiative and can be adjust themselves in time according to their actual situation. With its strong planning, government subsidies may blindly subsidize enterprises with poor performance and blindly construct high-tech projects.

We preliminarily analyzed the role of pilot policies in low-carbon cities in promoting the green technology innovation of enterprises. However, given that pilot policies themselves are still in the process of promotion, some limitations need to be monitored and analyzed. We used a multi-period double difference method to test the green technology innovation effect of the pilot policy. However, the third batch of the low-carbon city pilot work was carried out within a short period. In this case, considering the policy lag, corporate data covering a longer sample period are required for subsequent verification. In our analysis of the mechanism for alleviating financing constraints, our selected government subsidy indicators were not subdivided into scientific and technological innovation projects, could not fully reflect the incentive effects, and require further testing by mining relevant data. The financial constraints and investment risks of enterprises in green technological innovation are issues that need to be solved urgently in the development of low-carbon cities. Follow-up studies can start from the circular business model [52,53], analyze the effectiveness of circular economy in reducing resource consumption, waste and emissions, explore the feasibility of building a circular economy development model in high-carbon industries, and expand relevant research on low-carbon city pilot policies.

\section{Conclusions and Suggestions}

Based on a sample of A-share listed companies from 2005 to 2019, we analyzed the impact of the low-carbon city pilot policy on the green technology innovation of enterprises by using a multi-period double difference model. Based on the model results, we conducted a heterogeneity analysis, explored the direction of the pilot policy, and analyzed its impact mechanism to provide empirical basis for the follow-up implementation and promotion of this pilot policy. We obtained three key findings. First, the pilot policy of the low-carbon city promoted the innovation of enterprises in the field of green technology and significantly increased their number and proportion of green patent applications, especially green invention patents. Second, our heterogeneity analysis revealed that compared with central and western cities, the pilot policy was more conducive to the green technology innovation of enterprises in eastern cities. Meanwhile, compared with low-carbon emission industries, the pilot policy had a bigger role in promoting green innovation in high-carbon emission 
industries. Third, our mechanism analysis identified tax incentives and government subsidies as important fiscal and tax tools for fulfilling the roles of the low-carbon city pilot policy. By easing their financing constraints, enterprises could effectively promote green technology innovation. Tax incentives play an important role in promoting the green technology innovation of enterprises and mainly focus on green invention patents.

To further promote the development of a low-carbon economy and achieve a comprehensive green transformation of economic and social development, we propose the following countermeasures and suggestions: (1) actively promote the implementation and diffusion of pilot policies of low-carbon cities. The low-carbon pilot policy can promote the green technology innovation of enterprises, which is in line with China's current development situation and meets the needs of social development. To develop a low-carbon economy, we should actively promote the pilot work. On the one hand, we should sort out the achievements and shortcomings of the three batches of low-carbon city pilot work, summarize the work experience, and form typical cases to promote. On the other hand, according to their regional economic structure and recent development, we should gradually expand the scope of pilot cities and pursue carbon peak and carbon neutralization. (2) Carry out the pilot work of low-carbon cities according to local conditions. Based on the objective conditions of regions and industries, we should scientifically formulate an implementation plan of the pilot work to effectively control the amount and intensity of carbon emissions and gradually establish a pilot evaluation and retirement mechanism to supervise and restrict low-carbon pilot cities. (3) Attach importance to guiding the transformation and upgrading of high-carbon industries. Promoting the low-carbon development of high-carbon industries is an important task in the low-carbon pilot work. The pilot government can actively strive to levy carbon tax in the form of local tax. Through the collection of carbon tax and the establishment of green development fund, the government can guide and encourage high-carbon industries to promote the technological transformation and upgrading of traditional industries, and carry out green technology innovation, so as to give full play to the market main role of enterprises in developing low-carbon industries and developing clean technologies. At the same time, the green monitoring and evaluation system needs to be constructed, and the information of enterprise environmental violations should be included in the credit information. This will provide the basis for the government to implement fiscal and tax policies, so that the government can give full play to the role of tax incentives and government subsidies, ease the financing constraints of related enterprises, promote green technology innovation, and gradually optimize the regional industrial structure.

Author Contributions: Q.H. put forward the idea and revised the paper; J.M. analyzed the data and wrote the paper; W.S. and X.W. contributed to the conceptual framework of the methodology. All authors have read and agreed to the published version of the manuscript.

Funding: This research was funded by the Zhejiang Philosophy and Social Science Planning (No. 19XXJC02ZD), the National Natural Science Foundation of China (No. 71874092), the National Social Science Fund of China (No. 19AZD004).

Institutional Review Board Statement: Not applicable.

Informed Consent Statement: Not applicable.

Data Availability Statement: Not applicable. No new data were created or analyzed in this study.

Acknowledgments: Thanks to all the teachers and students in the research group that gave us so many suggestions in the process of our writing.

Conflicts of Interest: The authors declare no conflict of interest.

\section{References}

1. Zhao, X.; Sun, B. The Influence of Chinese Environmental Regulation on Corporation Innovation and Competitiveness. J. Clean. Prod. 2016, 112, 1528-1536. [CrossRef] 
2. Ramanathan, R.; Black, A.; Nath, P.; Muyldermans, L. Impact of environmental regulations on innovation and performance in the UK industrial sector. Manag. Decis. 2010, 48, 1493-1513. [CrossRef]

3. Wagner, M. On the Relationship between Environmental Management, Environmental Innovation and Patenting: Evidence from German Manufacturing Firms. Res. Pol. 2007, 36, 1587-1602. [CrossRef]

4. Chintrakarn, P. Environmental Regulation and U.S. States Technical Inefficiency. Econ. Lett. 2008, 100, 363-365. [CrossRef]

5. Zhang, C.; Lv, Y. Green Production Regulation and Enterprise R\&D Innovation: Impact and Mechanism Research. Bus. Manag. J. 2018, 40, 71-91. (In Chinese)

6. Frondel, M.; Horbach, J.; Rennings, K. End-of-Pipe or Cleaner Production? An Empirical Comparison of Environmental Innovation Decisions across Oecd Countries. Bus. Strateg. Environ. 2007, 16, 571-584. [CrossRef]

7. Horbach, J. Determinants of Environmental Innovation-New Evidence from German Panel Data Sources. Res. Pol. 2008, 37, 163-173. [CrossRef]

8. Xie, M.; Wang, J.; Liu, D. Environment Regulation, Technological Innovation and Corporate Performance. Nankai Bus. Rev. 2014, 17, 106-113. (In Chinese)

9. Jing, W.; Zhang, L. Environmental Regulation, Economic Opening and China's Industrial Green Technology Progress. Econ. Res. J. 2014, 49, 34-47. (In Chinese)

10. Jia, J.; Zhang, W. The Path Dependency of Green Technology Innovation and Environmental Regulation Analysis. Sci. Sci. Manag. $S$ 2014, 35, 44-52. (In Chinese)

11. Wang, F.; Guo, X. Effects of Environmental Regulation Intensity on Green Technological Innovation of Resource-based Industries. China Popul. Res. Environ. 2015, 25, 143-146. (In Chinese)

12. Qi, S.; Lin, S.; Cui, J. Do Environmental Rights Trading Schemes Induce Green Innovation? Evidence from Listed Firms in China. Econ. Res. J. 2018, 53, 129-143. (In Chinese)

13. Xie, R. Environmental regulation, induced innovation, and growth of green productivity in China. Ind. Econ. Res. 2017, 16, 38-48. (In Chinese)

14. Ye, Q.; Zeng, G.; Dai, S.; Wang, F. Research on the Effects of Different Policy Tools on China's Emissions Reduction Innovation: Based on the Panel Data of 285 Prefectural-level Municipalities. China Popul. Res. Environ. 2018, 28, 115-122. (In Chinese)

15. Peng, W.; Cheng, F.; Lu, J. A Study on the Threshold Effect of Environmental Regulation to Provincial Green Innovation Efficiency. South Chin. J. Econ. 2017, 35, 73-84. (In Chinese)

16. Xiao, L.; Gao, J.; Liu, S. The Change Trend of Green Technology Innovation Efficiency in China Based on Spatial GradientEmpirical Analysis of Provincial Panel Data. Soft Sci. 2017, 31, 63-68. (In Chinese)

17. Yu, K.; Hu, Y.; Song, Z. Environmental Regulation, Government Support and Green Technological Innovation: An Empirical Study Based on Resource-based Enterprises. J. Yunnan Univ. Financ. Econ. 2019, 35, 100-112. (In Chinese)

18. Zhang, J.; Geng, H.; Xu, G. Research on the Influence of Environmental Regulation on Green Technology Innovation. China Popul. Res. Environ. 2019, 29, 168-176. (In Chinese)

19. Wang, Z.; Cao, Y.; Lin, S. The Characteristics and Heterogeneity of Environmental Regulation's Impact on Enterprises' Green Technology Innovation-Based on Green Patent Data of Listed Firms in China. Stud. Sci. Sci. 2021, 39, 1-22. (In Chinese)

20. Yang, B.; Yin, Y. "Attending to One Thing and Losing Another" or "Killing Two Birds with One Stone"? -A Review of the Emission Reduction Effect after the Implementation of China's Carbon Emission Trading System. Collect. Essays Financ. Econ. 2020, 36, 104-112. (In Chinese)

21. Zhou, D.; Zhou, F.; Wang, X. Impact of Low-carbon Pilot Policy on the Performance of Urban Carbon Emissions and Its Mechanism. Resour. Sci. 2019, 41, 546-556. (In Chinese)

22. Li, S. The Influence of Pilot Policy of Low-carbon City on Power Energy Consumption Intensity: An Analysis Based on the Synthetic Control Method. Urban Probl. 2018, 37, 38-47. (In Chinese)

23. Cheng, J.; Yi, J.; Dai, S.; Xiong, Y. Can Low-Carbon City Construction Facilitate Green Growth? Evidence from China's Pilot Low-Carbon City Initiative. J. Clean. Prod. 2019, 231, 1158-1170. [CrossRef]

24. Chen, Q.; Qian, F. Can Environmental Protection Increase the Proportion of Producer Services in China: Research on Pilot Strategy of Low-carbon City. Econ. Rev. 2020, 41, 109-123. (In Chinese)

25. Lu, J.; Wang, X.; Liu, L. Industrial Structure Upgrading Effect of Low Carbon City Policy: Quasi-Natural Experimental Research Based on Low-Carbon City Pilot. J. Xi'an Jiaotong Univ. 2020, 40, 104-115. (In Chinese)

26. Song, H.; Sun, Y.; Chen, D. Assessment for the Effect of Government Air Pollution Control Policy: Empirical Evidence from "Low-carbon City" Construction in China. Manag. World 2019, 35, 95-108. (In Chinese)

27. Zhang, H. Can Low-carbon City Construction Reduce Carbon Emissions? Evidence from a Quasi-natural Experiment. Econ. Manag. J. 2020, 42, 25-41. (In Chinese)

28. Wang, Q.; She, S. Green Growth Effect Assessment of Chinese Low-carbon Pilot from the Perspective of Urban Heterogeneity. Soft Sci. 2020, 34, 1-8. (In Chinese)

29. She, S.; Wang, Q.; Zhang, A. Technological Innovation, Industrial Structure and Urban GTFP-Channel Test based on National Low-carbon City Pilots. Res. Econ. Manag. 2020, 41, 44-61. (In Chinese)

30. Wang, S.; Xu, Y. Environmental Regulation and Haze Pollution Decoupling Effect-Based on the Perspective of Enterprise Investment Preferences. Chin. Ind. Econ. 2015, 31, 18-30. (In Chinese) 
31. Porter, M.; Van der Linde, C. Toward a new conception of the environment-competitiveness relationship. J. Econ. Perspect. 1995, 9, 97-118. [CrossRef]

32. Jin, G.; Shen, K. Polluting Thy Neighbor or Benefiting Thy Neighbor: Enforcement Interaction of Environmental Regulation and Productivity Growth of Chinese Cities. Manag. World 2018, 34, 43-55. (In Chinese)

33. Lu, J.; Wang, X. The Impact of Low-Carbon Pilot Policies on Technological Innovation in Chinese Cities-Quasi-Natural Experiment Based on Low-Carbon City Pilot. J. China Univ. Geosci. 2019, 19, 128-141. (In Chinese)

34. Xiong, G.; Shi, D.; Li, M. The Effect of Low-carbon Pilot Cities on the Green Technology Innovation of Enterprises. Sci. Res. Manag. 2020, 41, 93-102. (In Chinese)

35. Zhuang, G. Policy Design Logic of Low-carbon City Pilots in China. China Popul. Res. Environ. 2020, 30, 19-28. (In Chinese)

36. Shen, N.; Liao, H.; Deng, R.; Wang, Q. Different Types of Environmental Regulations and the Heterogeneous Influence on the Environmental Total Factor Productivity: Empirical Analysis of China's Industry. J. Clean. Prod. 2019, 211, 171-184. [CrossRef]

37. Zhou, K.; Lu, Y.; Yang, H. Financial Constraints, Innovative Capability and Firms' Collaborative Innovation. Econ. Res. J. 2017, 52, 94-108. (In Chinese)

38. Zhang, X.; Liu, B.; Wang, T.; Chuntao, L. Credit Rent-seeking, Financing Constraint and Corporate Innovation. Econ. Res. J. 2017, 52,161-174. (In Chinese)

39. Sabrina, T.H. Financing Innovation: Evidence from R\&D Grants. Am. Econ. Rev. 2017, 107, 1136-1164.

40. Zhang, X.; Chen, G.; Hai, B. Financing Constraints, Government Subsidies and Performance of Industry-university-institute Collaborative Innovation. Stud. Sci. Sci. 2019, 37, 1529-1536. (In Chinese)

41. Huang, Z.; Liao, G.; Li, Z. Loaning Scale and Government Subsidy for Promoting Green Innovation. Technol. Forecast Soc. Chang. 2019, 144, 148-156. [CrossRef]

42. Liu, F.; Yang, Z.; Yang, X. Institutional Environment, Tax Incentives and Enterprise Innovation Investment. Manag. Rev. 2016, 28, 61-73. (In Chinese)

43. Atanassov, J.; Liu, X. Can Corporate Income Tax Cuts Stimulate Innovation? J. Financ. Quant. Anal. 2020, 55, 1415-1465. [CrossRef]

44. Fan, R.; Yu, M.; Chen, D. Does Corporate Tax Reduction Promote Corporate Innovation? J. Zhongnan Univ. Econ. Law. 2020, 63, 74-84. (In Chinese)

45. Li, W.; Du, J.; Zhang, H. Do R\&D Subsidies Really Stimulate Firms' R\&D Self-financing Investment: New Evidence from China's Listed Firms. J. Financ. Res. 2017, 60, 130-145. (In Chinese)

46. Zhao, S.; Qi, Q.; Zhang, J. A Study on the Impact of Government Subsidies on Corporate Innovation from the Perspective of Rent-seeking. Based on the Data of China's Listed Companies. East Chin. Econ. Manag. 2017, 31, 5-10. (In Chinese)

47. Xu, J.; Cui, J. Low-Carbon Cities and Firms' Green Technological Innovation. Chin. Ind. Econ. 2020, 37, 178-196. (In Chinese)

48. Li, W.; Zheng, M. Is it Substantive Innovation or Strategic Innovation? Impact of Macroeconomic Policies on Micro-enterprises' Innovation. Econ. Res. J. 2016, 51, 60-73. (In Chinese)

49. Colombo, M.; Croce, A.; Guerini, M. The Effect of Public Subsidies on Firms' Investment-Cash Flow Sensitivity: Transient or Persistent? Res. Pol. 2013, 42, 1605-1623. [CrossRef]

50. Popp, D. International Innovation and Diffusion of Air Pollution Control Technologies: The Effects of Nox and So2 Regulation in the Us, Japan, and Germany. J. Environ. Econ. Manag. 2006, 51, 46-71. [CrossRef]

51. Sheng, D.; Zhang, G. Environmental Regulations of Two Control Zones and Enterprise Total Factor Productivity Growth. Manag. World 2019, 35, 24-42. (In Chinese)

52. Geissdoerfer, M.; Pieroni, M.P.; Pigosso, D.C.; Soufani, K. Circular business models: A review. J. Clean. Prod. 2020, $277,123741$. [CrossRef]

53. Urbinati, A.; Rosa, P.; Sassanelli, C.; Chiaroni, D.; Terzi, S. Circular business models in the European manufacturing industry: A multiple case study analysis. J. Clean. Prod. 2020, 274, 122964. [CrossRef] 